\title{
Penerapan Model Group Investigation untuk Meningkatkan Hasil Belajar IPS tentang Kegiatan Ekonomi pada Siswa Kelas IV Sekolah Dasar
}

\section{Riska Purwoko}

Universitas Sebelas Maret

riskapurwoko@gmail.com

\section{Article History}

received 30/4/2021

\begin{abstract}
Education has an important role in developing the potential of a student. For this reason, innovation is needed in improving learning. The objective of this research is to improve learning outcome of social science about economic activity through the use of Group Investigation model for the fourth-grade students of SD Negeri Sidarum. This research is a Classroom Action Research (CAR). Subjects of the research were 19 fourth-grade students of SD Negeri Sidarum in the academic year of 2020/2021. Techniques of collecting data were learning outcomes observation, interview, and test. Validity of data in this research was analyzed using triangulation of sources and triangulation of technique. Data analysis used data reduction, data display, and drawing conclusion. The results showed that the graduation rate of students increased from $75 \%$ to $89.48 \%$. Based on the analysis and discussion of the research results, it can be concluded that the use of Group Investigation model can improve learning outcome of social science about economic activity for the fourth-grade students of SD Negeri Sidarum in the academic year of 2020/2021.
\end{abstract}

Keywords: Group Investigation, learning outcomes of IPS, economic activity

\section{Abstrak}

Pendidikan memiliki peran penting dalam mengembangkan potensi diri seorang siswa. Untuk itu perlunya inovasi dalam perbaikan pembelajaran. Tujuan penelitian ini adalah untuk meningkatkan hasil belajar IPS tentang kegiatan ekonomi pada siswa kelas IV SD Negeri Sidarum dengan menerapan model Group Investigation. Penelitian ini merupakan penelitian tindakan kelas. Subjek penelitian ini adalah siswa kelas IV yang berjumlah 19 siswa. Teknik pengumpulan data pada penelitian ini, yaitu observasi, wawancara, dan tes. Uji validitas data menggunakan triangulasi sumber dan triangulasi teknik. Analisis data melalui reduksi data, penyajian data, dan penarikan kesimpulan. Hasil penelitian menunjukkan bahwa tingkat kelulusan siswa meningkat dari $75 \%$ menjadi $89,48 \%$. Berdasarkan analisis dan pembahasan hasil penelitian dapat disimpulkan bahwa penerapan model Group Investigation dapat meningkatkan hasil belajar IPS tentang kegiatan ekonomi pada siswa kelas IV SD Negeri Sidarum tahun pelajaran 2020/2021.

Kata kunci: Group Investigation, hasil belajar IPS, kegiatan ekonomi 


\section{PENDAHULUAN}

Berdasarkan hasil observasi yang telah dilakukan di kelas IV SD Negeri Sidarum peneliti memperoleh data nilai rata-rata ulangan harian IPS siswa yaitu 62,11 dari jumlah siswa sebanyak 19 siswa. Hanya 57,90\% siswa yang mencapai $\geq$ KKM (67), dan $42,11 \%$ siswa belum mencapai KKM. Hal tersebut menunjukkan bahwa hasil belajar IPS masih rendah. Pembelajaran akan lebih menarik jika guru menerapkan model pembelajaran. Dengan penerapan model pembelajaran diharapkan perhatian siswa pada materi pelajaran dan hasil belajar meningkat. Guru harus tahu dan mampu mengaplikasikan model pembelajaran di dalam proses pembelajaran. Tidak hanya itu, guru harus kreatif dalam melaksanakan model pembelajaran dan memadukan antara model pembelajaran, materi, sumber belajar, lingkungan belajar, dan kurikulum demi tercapainya target dan tujuan pendidikan di sekolah dasar. Misalnya dengan menerapkan model Group Investigation.

Dalam pemilihan model pembelejaran Group Investigation tidak serta merta hanya memilih model pembelajaran. Tetapi peneliti juga harus menyesuaikan dengan materi pembelajaran yang sesuai. Selain itu peneliti memilih model ini juga didasarkan atas pendapat beberapa ahli. Menurut Mafune model pembelajaran kooperatif tipe Group Investigation dapat digunakan untuk mengembangkan kreativitas siswa, model pembelajaran kooperatif dirancang untuk menciptakan pembagian tanggung jawab siswa saat pembelajaran dan untuk membentuk manusia sosial (Rusman, 2014: 222). Huda (2013: 292) menyatakan bahwa model pembelajaran Group Investigation merupakan model pembelajaran kelompok yang mengharuskan siswa untuk menggunakan skill berpikir level tinggi yang menekankan pada heterogenitas dan kerja sama antar siswa.

Selain didasarkan oleh pendapat para ahli. Pemilihan model Group Investigation diperkuat oleh penelitian lain. Peneliti lain sudah membuktikan bagaimana Penerapan model Group Investigation dalam proses belajar mengajar. Penelitian Palupi (2017) yang menunjukkan bahwa model Group Investigation dengan media video dapat meningkatkan pembelajaran IPS siswa kelas IV. Penelitian lain yang relevan yaitu penelitian Nupiksani (2015) tentang peningkatan hasil belajar IPS melalui penerapan model pembelajaran Group Investigation pada siswa kelas VI SDN Rejoagung 01. Hasil penelitiannya yaitu model pembelajaran Group Investigation meningkatkan semangat belajar, melatih interaksi siswa, menumbuhkan sikap saling menghargai dan menghormati, aktivitas siswa meningkat, meningkatkan hasil belajar IPS. Kesamaan penelitian ini dengan penelitian Nupuksani yaitu sama-sama menggunakan model Group Investigation dan mata pelajaran IPS. Perbedaanya yaitu pada media, subjek penelitian, dan kelas yang diteliti.

Penerapan model Group Investigation sejalan dengan karakteristik siswa kelas IV SD yang diungkapkan Buhler, Buhler membagi 5 fase perkembangan anak. Fase keempat (9-11 tahun), fase ini disebut masa sekolah dasar. Disebut pula masa menyelidiki, mencoba, dan bereksperimen yang distimulus dorongan menyelidiki dan rasa ingin tahu (Sobur, 2003: 131-133).

Menurut Shoimin (2014: 81) langkah-langkah model Group Investigation yaitu: (1) pembagian kelompok secara heterogen, (2) guru menjelaskan maksud pembelajaran dan tugas kelompok, (3) guru memberikan tugas, (4) siswa berdiskusi kelompok, (5) menyampaikan hasil diskusi, (6) kelompok lain memberi tanggapan, (7) klarifikasi oleh guru, dan (8) evaluasi. Agar penerapan model Group Investigation dapat memberikan pengaruh maksimal terhadap peningkatan hasil belajar, maka seluruh langkah-langkah model Group Investigation harus dilaksanakan secara sistematis dan maksimal.

Berdasarkan uraian di atas, rumusan masalah penelitian ini adalah apakah penggunaan model Group Investigation dapat meningkatkan hasil belajar IPS tentang kegiatan ekonomi di kelas IV SD? 
Tujuan penelitian ini adalah untuk meningkatkan hasil belajar IPS tentang kegiatan ekonomi melalui model Group Investigation di kelas IV SD.

\section{METODE}

Penelitian ini merupakan Penelitian Tindakan Kelas (PTK). Penelitian ini dilaksanakan di SDN Sidarum tahun ajaran 2020/2021. Subjek penelitian ini adalah siswa kelas IV SD Negeri Sidarum dengan jumlah 19 siswa, terdiri dari 8 siswa laki-laki dan 11 siswa perempuan.

Alat pengumpul data yaitu lembar tes, lembar observasi dan pedoman wawancara. Analisis data terdiri dari reduksi data, penyajian data, dan penarikan kesimpulan. Guru melaksanakan pembelajaran dengan menerapkan langkah-langkah model Group Investigation. Observer dalam penelitian ini terdiri dari 2 orang.

Teknik uji validitas yang digunakan yaitu triangulasi sumber dan teknik. Penelitian ini merupakan penelitian tindakan kelas yang dilaksanakan selama dua siklus, terdiri dari 4 pertemuan. Pelaksanaan tindakan dilakukan melalui empat tahapan yaitu perencanaan, pelaksanaan, pengamatan/observasi, dan refleksi. Indikator kinerja penelitian yang ditargetkan dalam penelitian ini yaitu $80 \%$ untuk ketuntasan hasil belajar IPS siswa dengan KKM yaitu 67.

\section{HASIL DAN PEMBAHASAN}

Penelitian tindakan ini dilaksanakan selama 2 siklus. Siklus I dan II masingmasing terdiri dari dua pertemuan. Adapun langkah-langkah penggunaan model Group Investigation yaitu: (1) pembagian kelompok, (2) penjelasan maksud dan tujuan, (3) pembagian tugas, (4) investigasi, (5) penyampaian hasil diskusi (investigasi), (6) tanggapan kelompok lain, (7) klarifikasi guru, dan (8) evaluasi.

Berdasarkan hasil penelitian, hasil observasi guru dan siswa dalam penerapan model Group Investigation serta hasil belajar IPS tentang kegiatan ekonomi mengalami peningkatan di setiap siklusnya, perbandingan sebagai berikut.

Tabel 1. Perbandingan Hasil Observasi Guru, Observasi Siswa, dan Hasil belajar siswa tiap Siklus

\begin{tabular}{cccccc}
\hline No & Siklus & $\begin{array}{c}\text { Observasi } \\
\text { Guru }\end{array}$ & $\begin{array}{c}\text { Observasi } \\
\text { Siswa }\end{array}$ & $\begin{array}{c}\text { Rata-rata } \\
\text { Hasil } \\
\text { Belajar }\end{array}$ & $\begin{array}{c}\text { Persentase } \\
\text { Ketuntasan }\end{array}$ \\
\hline 1 & Siklus I & $74,61 \%$ & $75,39 \%$ & 73,61 & $75 \%$ \\
2 & Siklus II & $89,81 \%$ & $89,45 \%$ & 82,77 & $89,48 \%$ \\
\hline
\end{tabular}

Berdasarkan tabel 1, peningkatan persentase pembelajaran Guru dari siklus I $74,61 \%$ menuju siklus II $89,81 \%$ terjadi peningkatan sebesar $15,2 \%$. Peningkatan tersebut terjadi karena guru bersama observer sudah berdiskusi untuk memperbaiki kesalahan yang dilakukan pada siklus I. Pada siklus I guru masih beradaptasi dengan model Group Investigation karena guru masih pertama kali menerapkan model pembelajaran ini pertama kali. Pada siklus II guru sudah mulai terbiasa dengan langkah Group Investigation sehingga terjadi peningkatan hasil observasi guru yang dilaksanakan pada siklus II. Hal ini karena guru sudah memperbaiki pembelajaran secara signifikan pada siklus I, sehingga pada siklus II hasil observasi guru sudah sangat baik.

Peningkatan persentase pembelajaran Siswa dari siklus I 75,39\% menuju siklus II $89,45 \%$ terjadi peningkatan sebesar $14,06 \%$. Peningkatan ini terjadi karena terjadi perbaikan pembelajaran oleh siswa, pada siklus I siswa masih belum terbiasa melaksanakan pembelajaran dengan model Group Investigation, sehingga kegiatan siswa pada setiap langkah masih rendah terutama saat diskusi dan penyampaian 
tanggapan banyak siswa yang pasif. Pada siklus II kegiatan siswa meningkat karena guru membimbing siswa dalam setiap langkah pembelajaran.

Peningkatan hasil belajar siswa pada siklus I diperoleh rata-rata nilai siswa sebesar 73,61 dengan presentase ketuntasan siswa sebesar 75\%. Siklus II rata-rata nilai siswa dan presentase ketuntasan siswa meningkat, rata-rata nilai siswa 82,77 dengan presentase ketuntasan siswa $89,48 \%$. Dari hasil tersebut, disimpulkan bahwa terjadi peningkatan hasil belajar IPS tentang kegiatan ekonomi pada siswa kelas IV SD.

Data yang diperoleh peneliti menunjukkan bahwa hasil belajar mengalami peningkatan. Hal tersebut juga dapat dilihat pada penelitian yang dilakukan Rakasiwi (2017) yang menunjukkan bahwa penerapan model Group Investigation dengan media visual dapat meningkatkan hasil belajar IPS kelas IV SDN 1 Tamanwinangun. Hasil penelitian tersebut dapat dilihat dari presentase ketuntasan siswa selama tiga siklus. Siklus I ketuntasan siswa $50,00 \%$, siklus II 76,32\%, siklus III $86,84 \%$.

Dalam pembelajaran yang dilaksanakan selama siklus I dan siklus II terdapat kendala yang sering muncul yaitu banyak siswa yang hanya mampu menyampaikan kritik tetapi kurang memberikan saran karena belum terbiasa memecahkan masalah. Menurut Ratnasari, Santoso, dan Sarwono (2016: 50) bahwa dalam pembelajaran kooperatif peserta didik akan lebih mudah menemukan dan memahami konsep-konsep yang sulit bila saling mendiskusikan masalah dengan teman. Solusinya yaitu guru memotivasi siswa untuk memberikan kritik dan saran agar dapat memecahkan masalah dengan baik. Seperti yang dikatakan Widyanto (2017: 120) bahwa pembelajaran dengan Group Investigation dapat meningkatkan minat belajar siswa dengan cara berpartisipasi aktif dalam pembelajaran.

Kendala lainnya yaitu siswa kurang bertukar pendapat saat diskusi, beberapa siswa mendominasi saat diskusi. Kendala ini sesuai dengan salah satu kendala dalam penelitian Mulyorini dan Hariani (2014: 10) yaitu pada saat berdiskusi siswa tidak saling bertukar pendapat dan belum ada pembagian kerja yang jelas. Solusinya yaitu guru memotivasi siswa untuk lebih kritis dan saling memberi pendapat. Menurut Rusman (2014: 205) menyatakan bahwa pembelajaran cooperative mewadahi bagaimana siswa dapat bekerja sama dalam kelompok, bahwa tujuan kelompok adalah tujuan bersama.

\section{SIMPULAN}

Berdasarkan hasil penelitian dan pembahasan, disimpulkan bahwa penerapan model Group Investigation dapat meningkatkan hasil belajar IPS tentang kegiatan ekonomi pada siswa kelas IV SD Negeri Sidarum tahun pelajaran 2020/2021. Hal ini dapat dibuktikan dengan adanya peningkatan hasil belajar siswa. Pada siklus I diperoleh persentase ketuntasan siswa sebesar $75 \%$. Siklus II persentase ketuntasan siswa meningkat menjadi $89,48 \%$.

Berdasarkan simpulan di atas, peneliti memiliki saran yaitu penerapan model Group Investigation dapat dijadikan salah satu alternatif dalam peningkatan hasil belajar siswa pada materi atau mata pelajaran lain yang sesuai dengan karakteristik model Group Investigation.

\section{DAFTAR PUSTAKA}

Huda, M. (2013). Model-model Pengajaran dan Pembelajaran. Yogyakarta: Pustaka Pelajar.

Mulyorini \& Hariani, S. (2014). Penggunaan Media Flashcard dalam Model Pembelajaran Langsung untuk Meningkatkan Hasil Belajar Siswa pada Mata Pelajaran PKN Kelas V SDN Ngagel Rejo I/ 396 Surabaya. JPGSD, 02 (02), 112. Diperoleh dari http://jurnalmahasiswa.unesa.ac.id/index.php/jurnal-penelitianpgsd/article/view/10624/4211. 
Nupiksani, S. (2015). Meningkatkan Hasil Belajar IPS Melalui Penerapan Model Pembelajaran Group Investigation pada Siswa Kelas VI SDN Rejoagung 01 Kecamatan Semboro Kabupaten Jember. Pancaran, 4 (4), 13-24. Diperoleh dari https://jurnal.unej.ac.id/index.php/pancaran/article/view/2174.

Palupi, B.S. (2017). Peningkatan Pembelajaran IPS tentang Kegiatan Ekonomi Melalui Model Pembelajaran Kooperatif Tipe Group Investigation dengan Media Video di Kelas IV SD. Kalam Cendekia, 5 (2.1), 157-161. Diperoleh dari http://jurnal.fkip.uns.ac.id/index.php/pgsdkebumen/article/view/1009/7466.

Rakasiwi, I. (2017). Penerapan Model Group Investigation dengan Media Visual dalam Peningkatan Hasil Belajar IPS tentang Masalah Sosial pada Siswa Kelas IV SD Negeri 1 Tamanwinangun Tahun Ajaran 2016/2017. Kalam Cendekia, 5 (4.1), 306-309. http://www.jurnal.fkip.uns.ac.id/index.php/pgsdkebumen/article/view/0207/7569.

Ratnasari, M., Santoso, S., dan Sarwono. (2016). Efektifitas Hasil Geografi Materi Sumber Daya Alam (SDA) Menggunakan Model Pembelajaran Kooperatif Tipe Group Investigation (GI), Student Teams Achievement Divisions (STAD), dan Ceramah pada Siswa Kelas XI IPS SMA Negeri 1 Ponorogo. Jurnal GeoEco, 2 (1), 47-57. Diperoleh dari https://jurnal.uns.ac.id/GeoEco/article/view/8950/7966.

Rusman. (2014). Model-model Pembelajaran Mengembangkan Profesionalismen Guru. Jakarta: Rajawali Pers.

Shoimin, A. (2014). 68 Model Pembelajaran Inovatif dalam Kurikulum 2013. Yogyakarta: Ar-Ruzz Media.

Sobur, A. (2003). Psikologi Umum. Bandung: Pustaka Setia.

Widyanto, P. (2017). Penerapan Metode Pembelajaran Group Investigation Berbantuan Media Flanelgraf untuk Meningkatkan Minat dan Hasil Belajar Siswa pada Mata Pelajaran IPA. Jurnal Pendidikan Dasar Nusantara, 3 (1), 118-129. Diperoleh dari http://ojs.unpkediri.ac.id/index.php/pgsd/article/download/708/572/. 